\title{
Simplificação de Trabalho
}

No

momento em que o Govêrno Federal, bem como a Prefeitura do Distrito Federal, o I.A.P.I. e outros, se empenham numa patriótica campanha de simplificação de trabalho, nada mais oportuno que focalizar alǵumas normas e conceitos atuais sôbre a promoção de métodos de trabalho.

Os problemas da seleção, utilização, contrôle de métodos de trabalho, como o de treinamento para sua execução, à luz da moderna teoria das ciências administrativas, são considerados como os mais poderosos instrumentos de ação. Sobrepujam os demais fatôres inerentes à produtividade. Não há, nessa concepção, como se poderia supor, abstração ou desvalorização de outros problemas congêneres.

Ao contrário. Pôsto em paralelo com multifários problemas de administração e orǵanização, o campo dos métodos de trabalho assume destacada importäncia.

Nem ocorre, no caso, uma concepção emerǵente de simples teorias. Muito ao contrário, resulta de vultosas verificações práticas, feitas nas indústrias e instituições públicas. Chegou-se à conclusão de que a escolha dos métodos de trabalho, sua aprendizagem, instituição e contrôle representam o mais decisivo fator no equacionamento da produtividade. A partir dêsse fato, ruiram velhos conceitos, que tiveram de sofrer uma revisão. Dentre êles o problema relativo a chefias.

Foram superadas, nesse campo, as clássicas discriminações de "qualidades de chefia", a que, desde FAYOL, se vinha emprestando tão grave importância. O que mais importa, no momento, não é recrutar e selecionar chefes que possuam tais ou quais qualificações. O problema é outro. Consiste em conseguir que os chefes sejam capazes de desempenhar certas funções, reconhecidas cardeais, sem as quais a chefia se confunde e assemelha à execução. 
Aquêle tipo característico de chefe, sempre infatigável, separado de seus subordinados por uma cortina de papelório, perdeu de todo a significação. Não chefia. Executa.

Era fatal a evolução. Primeiro, a época em se admitia que o executante pudesse, com o decorrer do tempo, descobrir o melhor método de trabalho. A seguir, graças à memoráveis observações de TAYLOR e de seus seguidores, acreditava-se que a solução ideal seria confiar a promoção dos métodos de trabalho a técnicos. Mais adiante, pontificavam os elementos "staff". Por fim, a Psicotécnica e a Sociologia do Trabalho vieram evidenciar a supremacia dos resultados, quando tais encaróos eram deveres dos próprios chefes imediatos. Os resultados foram mais eficazes, mais rápidos, mais econômicos.

Os modernos administradores já não dão a mesma ênfase às tão famosas quanto variadas "qualidades de chefes", tão difíceis de encontrar. $O$ que se espera do chefe não é apenas a presença daqueles atributos pessoais que mais exornam sua personalidade, que influem na produtividade.

O que se espera da chefia, a par de outras de menor monta, são as três capacidades fundamentais: treinar seus subordinados, assegurar-1hes apropriadas relações humanas no trabalho e melhorar os métodos de trabalho. Essas capacidades, ao contrário do que se passa com as "qualidades", são passiveis de formação profissional, bem assim fáceis de obter.

Assim, o êxito de uma Campanha de Simplificação está em mãos dos chefes, especialmente os das menores unidades de trabalho.

A promoção de simplificação passa a ser um dos deveres inerentes às chefias. Mediante curto treinamento, qualquer chefe estará em condições de levá-la a bom têrmo. Não é tarefa complexa, nem insuperável, que exija conhecimentos profundos ou esotéricos. Qualquer chefe, convencido de que sempre será possível meIhorar os métodos de trabalho, compenetrado de que isso constitui um de seus deveres fundamentais, verificará do que será capaz, pelos resultados compensadores que obterá.

Portanto, pelo seu valor relativo, a questão dos métodos de trabalho é a pedra de toque da administração. Serve de medida, pois o mais importante não é o valor quali-quantitativo do traba- 
- Tho, mas a natureza do método que possibilitou tal resultado. Conseguir selecionar, favorecer sua aceitação pelos subordinados e promover o treinamento em melhores métodos passou a ser um dos mais valiosos deveres dos chefes.

Associando-se à meritória campanha de simplificação do trabalho, em boa hora iniciada pelo Govêrno Federal, e tendo em vista a natural limitação do raio de ação direta dos órgãos dela incumbidos, a "Revista do Serviço Público" chama a atenção de seus leitores para a publicação que vem fazendo do Manual de Simplificação do Trabalho adotado pelo I.A.P.I., para orientar os respectivos chefes na aplicação das técnicas de análise e simplificação das atividades desenvolvidas sob sua gestão.

A parte publicada no presente número - terceira das quatro em que está dividido o referido Manual - trata da Análise do Volume do Trabalho.

Nos dois números anteriores, além de publicarmos a primeira e a segunda partes do Manual, respectivamente - Análise da Distribuição e Análise da Seqüência do Trabalho - focalizamos as principais bases da organização e do funcionamento da simplificação do trabalho no I.A.P.I., atividade que aquêle Instituto resolveu, louvàvelmente, exercer em caráter permanente. 